\title{
Endogenous opiates and the control of breathing in normal subjects and patients with chronic airflow obstruction
}

\author{
MVZ TABONA, N AMBROSINO, PETER J BARNES \\ From the Department of Medicine (Respiratory Division), Royal Postgraduate Medical School, London
}

ABSTRACT To investigate the role of endorphins in central respiratory control, the effect of $\underset{f}{\infty}$ naloxone, a specific opiate antagonist, on resting ventilation and ventilatory control was 웅 investigated in a randomised double-blind, placebo-controlled study of normal subjects and patients with chronic airways obstruction and mild hypercapnia due to longstanding chronic $Z$ bronchitis. In 13 normal subjects the ventilatory response to hypercapnia increased after an $\underset{\mathbb{D}}{\gtrless}$ intravenous injection of naloxone $(0.1 \mathrm{mg} / \mathrm{kg})$, ventilation $(\dot{\mathrm{VE}})$ at a $\mathrm{PCO}_{2}$ of $8.5 \mathrm{kPa}$ increasing from $55 \cdot 6 \pm \operatorname{SEM} 6 \cdot 2$ to $75 \cdot 9 \pm 8 \cdot 21 \mathrm{~min}^{-1}(\mathrm{p}<0 \cdot 001)$ and the $\triangle \dot{\mathrm{VE}} / \triangle \mathrm{PCO}_{2}$ slope increasing from $\stackrel{\Phi}{\sim}$ $28 \cdot 6 \pm 4 \cdot 4$ to $34 \cdot 2 \pm 4.21 \mathrm{~min}^{-1} \mathrm{kPa}^{-1}(\mathrm{p}<0 \cdot 05)$. There was no significant change after placebo $\vec{\bullet}$ (saline) injection. Naloxone had no effect on resting ventilation or on the ventilatory response to hypoxia in normal subjects. In all six patients naloxone significantly $(p<0.02)$ increased mouth 0 occlusion pressure $\left(\mathrm{P}_{0.1}\right)$ responses to hypercapnia. Although there was no change in resting respiratory frequency or tidal volume patients showed a significant $(p<0.01)$ decrease in inspiratory timing (Ti/Ttot) and increase in mean inspiratory flow (VT/Ti) after naloxone. These results indicate that endorphins have a modulatory role in the central respiratory response to $\underset{\Omega}{\mathbb{Q}}$ hypercapnia in both normal subjects and patients with airways obstruction. In addition, they have $\overrightarrow{0}$ an inhibitory effect on the control of tidal breathing in patients with chronic bronchitis.

Exogenous opiates have long been known to depress respiration and diminish the ventilatory response to hypoxia and hypercapnia. ${ }^{1}$ These effects are blocked by naloxone, a potent and specific opiate receptor antagonist. ${ }^{2}$ Endogenous opiates (endorphins) ${ }^{34}$ and opiate receptors have been found in high concentration in the solitary nuclei and area postrema of the medulla, ${ }^{5}$ areas closely associated with central control of respiration. This has suggested that endorphins may play a part in the central control of breathing.

Animal studies have indicated that endorphins may be important in central respiratory control. Injection of methionine-enkephalin into the brain stem induced a fall in resting ventilation and tidal volume in cats. ${ }^{6}$ Intracisternal injection of human B-endorphin produced a similar effect in dogs and also caused diminution of respiratory sensitivity to

Address for reprint requests: Dr PJ Barnes, Cardiovascular Research Institute, School of Medicine, University of California, San Francisco 94143 , USA. carbon dioxide. ${ }^{7}$ Naloxone led to increased phreni@ nerve output in cats, ${ }^{8}$ shortened apnoeic episodes in newborn asphyxiated rabbits, ${ }^{9}$ and an increase ${ }_{B}$. respiratory response to carbon dioxide in dogs, ${ }^{10}$ suggesting that endorphins may influence centraß control of respiration.

In normal man naloxone had no effect on tida volume or on end-tidal carbon dioxide. "In a smals study naloxone had no significant effect on ventilatory responses to hypercapnia or hypoxia in normal subjects. ${ }^{12}$ In patients with chronic airway obstruction, however, naloxone increased the ability to compensate for an additional inspiratory resistance and in some patients increased the response to carbotr dioxide. ${ }^{13}$ This study, however, lacked placeb\& controls, making interpretation difficult. As the role of endogenous opiates in the control of breathing remains uncertain, we have studied the effects of naloxone on respiration and ventilatory control irs normal subjects and in patients with chronic airway obstruction in a double-blind randomised study. 
Table 1 Forced expiratory volume in one second $\left(F E V_{1}\right)$, vital capacity (VC), and mixed venous carbon dioxide tension $\left(\mathrm{PDCO}_{2}\right)$ in patients with chronic airways obstruction as a result of longstanding chronic bronchitis

\begin{tabular}{lllll}
\hline $\begin{array}{l}\text { Patient } \\
\text { No }\end{array}$ & $\begin{array}{l}\text { Age } \\
(y)\end{array}$ & $\begin{array}{l}F E V_{1} \\
(l)\end{array}$ & $\begin{array}{l}V C \\
(l)\end{array}$ & $\begin{array}{l}P \bar{v} C O_{2} \\
(k P a)\end{array}$ \\
\hline 1 & 56 & 0.41 & $2 \cdot 49$ & $7 \cdot 1$ \\
2 & 57 & 0.56 & $2 \cdot 57$ & $6 \cdot 9$ \\
3 & 62 & 0.90 & 1.96 & $7 \cdot 0$ \\
4 & 63 & 0.46 & 1.95 & $7 \cdot 7$ \\
5 & 69 & 0.53 & $2 \cdot 24$ & $7 \cdot 2$ \\
6 & 71 & 0.67 & $2 \cdot 76$ & $7 \cdot 3$ \\
Mean & 63.0 & 0.59 & $2 \cdot 33$ & $7 \cdot 2$ \\
\hline
\end{tabular}

\section{Methods}

We studied 13 normal subjects ( 10 of them men) aged 23-43 years, none of whom took medication or smoked; and six patients with severe chronic obstructive airways disease with a forced expiratory volume in one second $\left(\mathrm{FEV}_{\mathrm{1}}\right)$ of less than 1 litre (table 1). All had mild hypercapnia (mixed venous carbon dioxide tension $\left.\left(\mathrm{P}_{\overline{\mathrm{v}}} \mathrm{CO}_{2}\right) 6 \cdot 9-7 \cdot 7 \mathrm{kPa}\right)$. All medication was stopped 12 hours before the study and tea and coffee were avoided by all subjects for the previous six hours. The research ethics committee approved the investigation and all subjects gave informed consent.

To avoid the effect of a mouthpiece, resting ventilation was measured non-invasively from body surface movements with a respiratory inductance plethysmograph (Respitrace) consisting of thoracic and abdominal belts. This was calibrated by an isovolume manoeuvre as previously described ${ }^{14}$ and gave an accuracy compared with simultaneous spirometric measurements in the semi-recumbent posture of $\pm 10 \%$ in both normal subjects and patients with airways obstruction. Measurements were made with the subject lying quietly and when ventilation showed little variation a sample over five minutes was recorded (Sanborn recorder) with a paper speed of $1 \mathrm{~cm} / \mathrm{s}$. Resting respiratory frequency, tidal volume (VT), inspiratory timing (Ti/Ttot), and mean inspiratory flow (VT/Ti) were measured. ${ }^{15}$

Respiratory sensitivity to carbon dioxide was measured by a modification of the rebreathing method of Read. ${ }^{16}$ Subjects rebreathed a 5\% carbon dioxide in $95 \%$ oxygen gas mixture from an anaesthetic bag contained in a glass bottle and ventilation was measured by a dry gas meter (Parkinson Cowan CD4). Gas was continuously sampled at the mouth by an infared carbon dioxide meter (Capnograph, Godart) and the sampled gas was returned to the rebreathing bag. In the patients mouth pressure in the first 0.1 second of an occluded breath $\left(\mathrm{P}_{0.1}\right)$ was measured with a specially designed valve, and measurements were made every 30 seconds during rebreathing. $P_{0.1}$ is independent of the compliance and flow resistance of the lung, ${ }^{1718}$ and therefore provides a better index of central respiratory drive than does ventilation in patients with airway obstruction, whose ventilatory response may be limited. Results were analysed by plotting ventilation (VE) and $\mathrm{P}_{0.1}$ against $\mathrm{PCO}_{2}$. The resulting plots were linear and the slopes determined by linear regression analysis $\left(\triangle \dot{\mathrm{VE}} / \triangle \mathrm{PCO}_{2} ; \triangle \mathrm{P}_{0.1} / \triangle \mathrm{PCO}_{2}\right)$. $\dot{\mathrm{V}} \mathrm{E}$ or $\mathrm{P}_{0.1}$ at a fixed $\mathrm{PCO}_{2}(8 \cdot 5 \mathrm{kPa})$ was also determined.

Hypoxic responses were measured in normal subjects by a modification of the method of Rebuck and Campbell. ${ }^{19}$ Subjects rebreathed a gas mixture of $7 \%$ carbon dioxide in air and ventilation was measured as above. Before rebreathing subjects breathed quietly on the mouthpiece connected to air and end-tidal $\mathrm{PCO}_{2}$ was estimated. This was then maintained at the same level $( \pm 0 \cdot 2 \%)$ throughout the rebreathing period by a scrub circuit (containing soda lime) with a variable flow. Arterial oxygen saturation $\left(\mathrm{SaO}_{2}\right)$ was measured continuously by an ear oximeter (Hewlett Packard). Rebreathing continued until the $\mathrm{SaO}_{2}$ fell to $70 \%$. The resulting plots of $\dot{V E}$ against $\mathrm{SaO}_{2}$ were linear and the slopes $\left(\triangle \dot{\mathrm{V}} \mathrm{E} / \triangle \mathrm{SaO}_{2}\right)$ were determined by linear regression analysis.

Baseline measurements of resting ventilation and hypercapnia response were made in all subjects, and hypoxic response in eight normal subjects. Subjects were then given either naloxone $0.1 \mathrm{mg} / \mathrm{kg}$ or volume-matched saline in double-blind manner on consecutive days. This large dose of naloxone was chosen to block endogenous opiate receptors completely. Measurements were repeated 10 minutes after injection, which is sufficient time to allow penetration of naloxone into the brain; and studies were completed within 40 minutes of injection, which is well within the half life of the drug. ${ }^{20}$ No subjects knew whether they had received naloxone or placebo and no adverse effects were reported. Heart rate and blood pressure were recorded periodically.

Results were analysed statistically by the paired Student's $t$ test.

\section{Results}

NORMAL SUBJECTS

There was no significant change in resting minute ventilation $(\dot{\mathrm{V}} \mathrm{E})$, respiratory frequency, tidal volume (VT), Ti/Ttot or $\mathrm{VT} / \mathrm{Ti}$ with either naloxone or placebo (table 2). There was no significant change in hypnotic response $\left(\triangle \dot{\mathrm{V}} E / \triangle \mathrm{SaO}_{2}\right)$ after either placebo or naloxone in eight subjects, although the hypoxic response showed considerable variability, as reported by others. ${ }^{21}$ In 13 subjects the mean response to 
Table 2 Mean ( $\pm S E M)$ respiratory responses to naloxone and placebo in normal subjects

\begin{tabular}{|c|c|c|c|c|}
\hline & \multicolumn{2}{|l|}{ Placebo } & \multicolumn{2}{|l|}{ Naloxone } \\
\hline & Before & After & Before & After \\
\hline 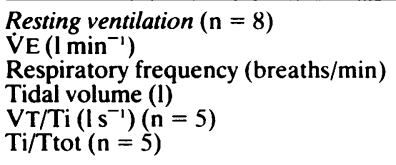 & $\begin{aligned} 5 \cdot 81 & \pm 0 \cdot 30 \\
14 \cdot 5 & \pm 0 \cdot 7 \\
0 \cdot 40 & \pm 0 \cdot 07 \\
0 \cdot 26 & \pm 0 \cdot 02 \\
0 \cdot 38 & \pm 0 \cdot 01\end{aligned}$ & $\begin{aligned} 5 \cdot 99 & \pm 0 \cdot 26 \\
13 \cdot 9 & \pm 0 \cdot 9 \\
0 \cdot 43 & \pm 0 \cdot 05 \\
0 \cdot 35 & \pm 0 \cdot 05 \\
0 \cdot 33 & \pm 0 \cdot 03\end{aligned}$ & $\begin{array}{c}6 \cdot 21 \pm 0 \cdot 28 \\
15 \cdot 7 \pm 1 \cdot 1 \\
0 \cdot 40 \pm 0 \cdot 07 \\
0 \cdot 29 \pm 0 \cdot 09 \\
0 \cdot 36 \pm 0 \cdot 03\end{array}$ & $\begin{array}{c}5 \cdot 75 \pm 0 \cdot 25 \\
14 \cdot 3 \pm 1 \cdot 0 \\
0 \cdot 40 \pm 0 \cdot 07 \\
0 \cdot 32 \pm 0 \cdot 03 \\
0 \cdot 33 \pm 0 \cdot 02\end{array}$ \\
\hline $\begin{array}{l}\text { Hypercapnic response }(\mathrm{n}=13) \\
\triangle \mathrm{VE} / \triangle \mathrm{PCO}_{2}\left(1 \mathrm{~min}^{-1} \mathrm{kPa}^{-1}\right) \\
\dot{\mathrm{VE}} \text { at } \mathrm{PCO}_{2}=8.5 \mathrm{kPa}\left(\mathrm{Imin}^{-1}\right)\end{array}$ & $\begin{array}{l}25.9 \pm 3.4 \\
56 \cdot 7 \pm 6.9\end{array}$ & $\begin{array}{l}26 \cdot 7 \pm 3 \cdot 3 \\
58 \cdot 4 \pm 6 \cdot 6\end{array}$ & $\begin{array}{l}28 \cdot 6 \pm 4 \cdot 4 \\
56 \cdot 6 \pm 6 \cdot 2\end{array}$ & $\begin{array}{l}34 \cdot 2 \pm 4 \cdot 2^{*} \\
75 \cdot 9 \pm 8 \cdot 3^{* * *}\end{array}$ \\
\hline $\begin{array}{l}\text { Hypoxic response }(\mathrm{n}=8) \\
\triangle \mathrm{VE} / \triangle \mathrm{SaO}_{2}(1 / \mathrm{min} / \% \text { sat })\end{array}$ & $1 \cdot 44 \pm 0 \cdot 26$ & $1 \cdot 68 \pm 0 \cdot 34$ & $1 \cdot 35 \pm 0 \cdot 40$ & $1.49 \pm 0.31$ \\
\hline
\end{tabular}

Significance of difference between values before and after injection: ${ }^{* * *} p<0 \cdot 001 ;{ }^{*} p<0.05$.

carbon dioxide was significantly increased after naloxone whether measured by slope $\left(\triangle \dot{V} E / \triangle \mathrm{PCO}_{2}\right)$ or by ventilation at a fixed carbon dioxide tension ( $\mathrm{VE}$ at $\mathrm{PCO}_{2}=8.5 \mathrm{kPa}$ ) but there was no significant change after placebo (fig 1). There was no significant difference between the preinjection hypercapnic responses on the different study days. There was considerable individual variability in response to naloxone, some subjects showing a considerable response whereas others showed little change. There was no significant correlation, however, between magnitude of response to naloxone and the initial sensitivity to carbon dioxide. Reproducibility was assessed in one subject who showed a large response to naloxone, which was observed under double-blind conditions on three separate occasions.

\section{PATIENTS}

There were no significant changes in either resting $\dot{V E}$, respiratory frequency, or VT in the patients, although there was a significant fall in Ti/Ttot $(p<$ $0.01)$ and a significant rise in VT/Ti $(p<0.01)$ after naloxone, but not after placebo (table 3 , fig 2 ). As expected, the ventilatory responses to carbon dioxide were much lower than in normal subjects. The slope of the ventilatory response to hypercapnia $(\triangle \dot{V} E)$ $\left.\triangle \mathrm{PCO}_{2}\right)$ and the ventilation at $\mathrm{PCO}_{2}=8.5 \mathrm{kPa}$ increased with naloxone but this trend did not achieve significance. The slope of the $P_{0.1}$ response $\left(\Delta P_{0.1}\right)$ $\left.\triangle \mathrm{PCO}_{2}\right)$ was, however, significantly greater $(\mathrm{p}<$ 0.02 ) after naloxone than after placebo, and the $P_{0.1}$ at $\mathrm{PCO}_{2}=8.5 \mathrm{kPa}$ was significantly higher $(\mathrm{p}<0.02)$ after naloxone than after placebo (fig 3 ).

There were no significant changes in heart rate or blood pressure with naloxone in either normal subjects or patients.

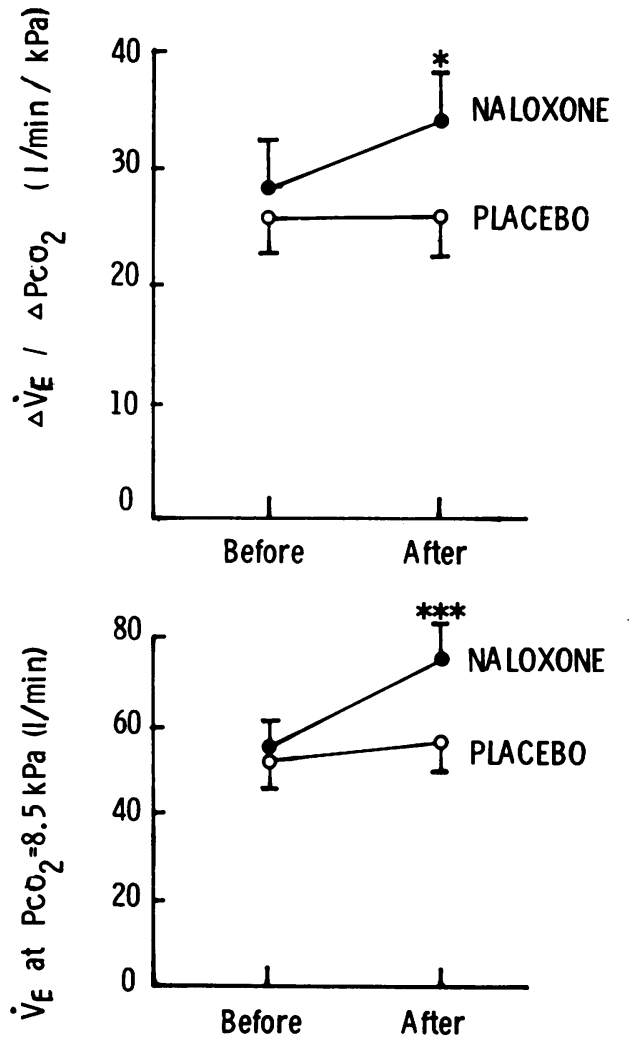

Fig 1 Slope of ventilatory response (means \pm SEM) to hypercapnia $\left(\triangle \dot{V} E / \triangle P C O_{2}\right)$ (above) and ventilation at a $\mathrm{PCO}_{2}$ of $8.5 \mathrm{kPa}$ (below) in 13 normal subjects before and after injection of naloxone or placebo. Significance of difference between values before and after injection: ${ }^{* * *} p<$ $0.001 ;{ }^{*} p<0.05$. 
Table 3 Mean ( $\pm S E M)$ respiratory responses to naloxone and placebo in six patients with chronic bronchitis

\begin{tabular}{|c|c|c|c|c|c|c|}
\hline & \multicolumn{2}{|l|}{ Placebo } & \multicolumn{4}{|c|}{ Naloxone } \\
\hline & Before & After & Before & & After & \\
\hline $\begin{array}{l}\text { Resting ventilation } \\
\left.\text { VE (l min }{ }^{-1}\right) \\
\text { Respiratory frequency (breaths/min) } \\
\text { Tidal volume (l) } \\
\text { VT/Ti }\left(1 \mathrm{~s}^{-1}\right) \\
\text { Ti/Ttot }\end{array}$ & $\begin{array}{cl}8.32 & \pm 0.75 \\
17.9 & \pm 2.7 \\
0.50 & \pm 0.06 \\
0.47 & \pm 0.06 \\
0.31 & \pm 0.03\end{array}$ & $\begin{array}{cl}8.04 & \pm 0.77 \\
17.2 & \pm 2.1 \\
0.49 & \pm 0.05 \\
0.47 & \pm 0.07 \\
0.31 & \pm 0.03\end{array}$ & $\begin{array}{c}8 \cdot 06 \\
18 \cdot 5 \\
0 \cdot 47 \\
0 \cdot 45 \\
0 \cdot 32\end{array}$ & $\begin{array}{l} \pm 0.77 \\
\pm 2.4 \\
\pm 0.05 \\
\pm 0.07 \\
\pm 0.03\end{array}$ & $\begin{array}{c}9 \cdot 43 \\
18 \cdot 5 \\
0 \cdot 52 \\
0 \cdot 66 \\
0 \cdot 26\end{array}$ & $\begin{array}{l} \pm 1 \cdot 44 \\
\pm 2 \cdot 5 \\
\pm 0.05 \\
\pm 0 \cdot 12^{* * *} \\
\pm 0.02^{* * *}\end{array}$ \\
\hline $\begin{array}{l}\text { Hypercapnic response } \\
\triangle \mathrm{VE} / \triangle \mathrm{PCO}\left(1 \mathrm{~min}^{-1} \mathrm{kPa}^{-1}\right) \\
\triangle \mathrm{VE} \text { at } \mathrm{PCO}_{2}=8.5 \mathrm{kPa}^{\left.-1 \mathrm{~min}^{-1}\right)} \\
\triangle \mathrm{P}_{0.1} / \triangle \mathrm{PCO}_{2} \\
\mathrm{P}_{0.1} \text { at } \mathrm{PCO}_{2}=8.5 \mathrm{kPa}(\mathrm{kPa})\end{array}$ & $\begin{aligned} 3 \cdot 63 & \pm 0 \cdot 60 \\
15 \cdot 1 & \pm 0 \cdot 7 \\
0 \cdot 042 & \pm 0 \cdot 008 \\
1 \cdot 13 & \pm 0 \cdot 17\end{aligned}$ & $\begin{array}{cl}3 \cdot 44 & \pm 0.49 \\
14 \cdot 5 & \pm 0 \cdot 8 \\
0 \cdot 040 & \pm 0 \cdot 009 \\
1 \cdot 10 & \pm 0 \cdot 17\end{array}$ & $\begin{array}{c}3 \cdot 10 \\
14 \cdot 2 \\
0 \cdot 038 \\
1 \cdot 08\end{array}$ & $\begin{array}{l} \pm 0.51 \\
\pm 0.6 \\
\pm 0.009 \\
\pm 0.15\end{array}$ & $\begin{array}{c}3 \cdot 87 \\
15 \cdot 7 \\
0 \cdot 065 \\
1 \cdot 36\end{array}$ & $\begin{array}{l} \pm 1.05 \\
\pm 1.0 \\
\pm 0.013^{* *} \\
\pm 0 \cdot 21^{* *}\end{array}$ \\
\hline
\end{tabular}

Significance of difference between values before and after injection: ${ }^{* * *} \mathrm{p}<0 \cdot 01 ;{ }^{* *} \mathrm{p}<0 \cdot 02$.
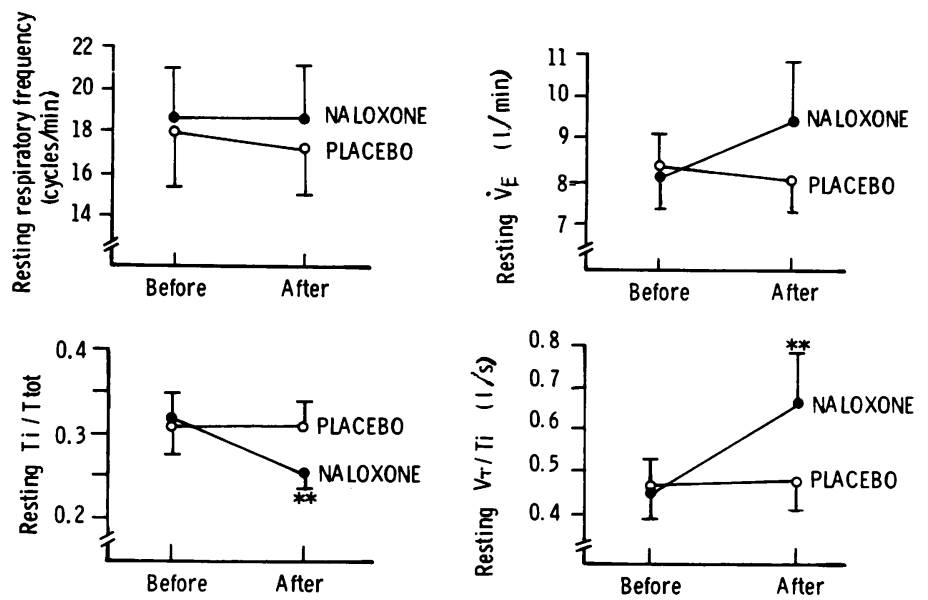

Fig 2 Resting ventilation in six patients with chronic obstructive airway disease before and after injection of naloxone or placebo: mean $( \pm S E M)$ respiratory frequency, minute ventilation $(\dot{V} E)$, inspiratory timing (Ti/Ttot), and mean inspiratory flow (VT/Ti). Significance of difference between values before and after injection: ${ }^{* *} p<0.01$.

\section{Discussion}

Our results indicate that endorphins have played a modulatory role in the control of breathing. In both normal subjects and patients with chronic airflow obstruction and mild hypercapnia the ventilatory response to carbon dioxide was significantly increased by naloxone given in a randomised double-blind manner. In normal subjects both the slope of the hypercapnic response and the ventilation at a given carbon dioxide tension were increased. In patients the hypercapnic response measured by slope and position was similarly increased when $P_{0.1}$ was used to measure response. Although the ventilatory response to hypercapnia showed a tendency to increase with naloxone in the patients this trend did not achieve statistical significance because of the greater variability of ventilatory response and the mechanical limitations of severe airflow obstruction that greatly reduced the ventilatory response. These results suggest that endorphins have an inhibitory effect in the central respiratory response to hypercapnia. In normal subjects there was individual variability in the magnitude of the effect of naloxone on the hypercapnic response, and some subjects were not affected by naloxone. There was no correlation, however, between the magnitude of response and the initial ventilatory response to hypercapnia, indicating that differing influences of endorphins are unlikely to account for individual variations in the ventilatory response to carbon dioxide. ${ }^{22}$ All six patients with chronic bronchitis, however, showed an increase in the $P_{0.1}$ response to carbon dioxide with naloxone. Our results are at variance with those of Fleetham $e t$ $a l,{ }^{12}$ who found no significant effect of naloxone on hypercapnic responses in six normal subjects. Although they found an increase in the slope of the relationship between ventilation and carbon dioxide 

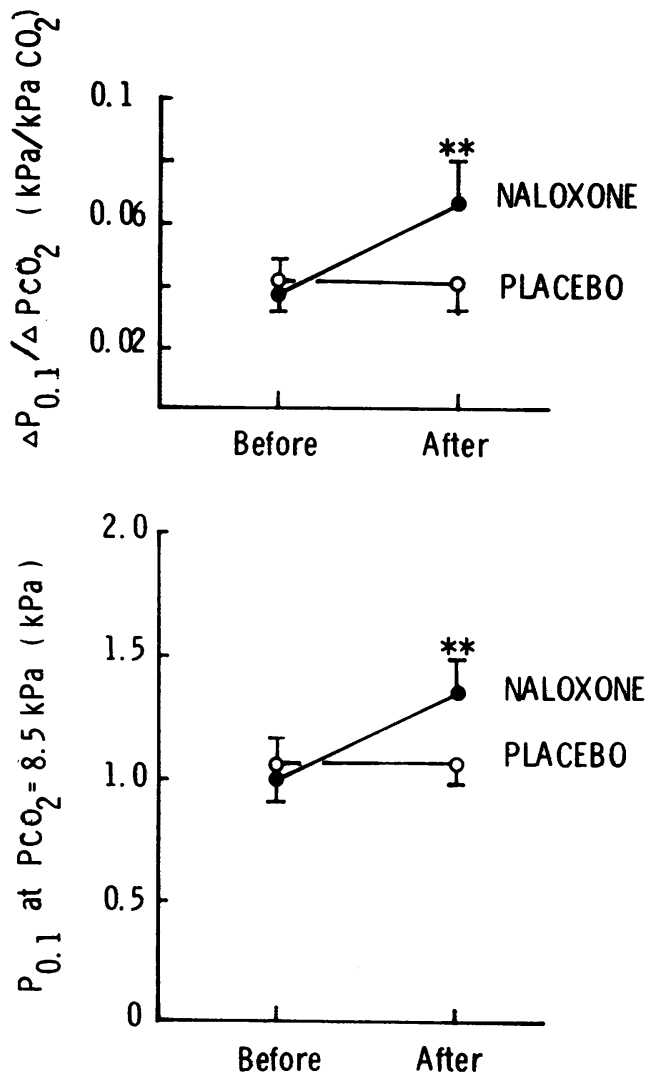

Fig 3 Slope of mouth occlusion pressure response to hypercapnia $\left(\triangle P_{0.1} / \triangle P\left(\mathrm{CO}_{2}\right)\right.$ (above) and $P_{0.1}$ response at a $\mathrm{PCO}_{2}$ of $8.5 \mathrm{kPa}$ (below) (means $\pm \mathrm{SEM}$ ) in six patients with chronic obstructive airway disease before and after injection of naloxone or placebo. Mean \pm SEM values shown; Significance of difference between values before and after injection: ${ }^{* *} p<0.02$.

tension with naloxone they observed a similar change with placebo, whereas in our study no placebo response was observed. Santiago et al ${ }^{13}$ found that naloxone increased the $P_{0.1}$ response to hypercapnia in some patients with mild airways obstruction and increased the respiratory effort elicited by an added inspiratory airway resistance in others. These responses were not compared with placebo, however, and must therefore be interpreted with some caution.

In normal subjects naloxone had no significant effect on resting ventilation or pattern of breathing. In the patients, although naloxone did not affect tidal volume or respiratory frequency, there was a significant increase in resting mean inspiratory flow (VT/Ti) and decrease in inspiratory timing ( $\mathrm{Ti} / \mathrm{Ttot})$, which may indicate an increased neuronal output from the respiratory centre. This suggests that $\stackrel{\bar{s}}{+}$ endorphins may have a modulatory influence on tidal $\bar{c}$ breathing in patients with chronic airways obstruction.

Hypoxic drive is mediated mainly through $\stackrel{\mathbb{D}}{\Omega}$ peripheral chemoceptors in the carotid body. ${ }^{23} \stackrel{\infty}{\infty}$ Recent histochemical studies have shown a high $\vec{\circ}$

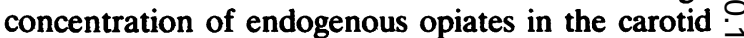
body of cats, ${ }^{24}{ }^{25}$ suggesting that endorphins may have $\vec{\omega}$

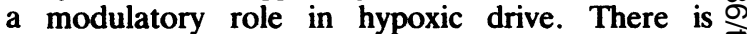
experimental evidence that naloxone does increase $\overrightarrow{\vec{x}}$ hypoxic responses in the cat. ${ }^{26}$ In our study no significant change in hypoxic responses after. naloxone was found, although the variability of this response may have masked a small effect.

The effects of naloxone are small, however. More than one type of opiate receptor has been defined, ${ }^{27} 28 \mathrm{~J}$ and whereas naloxone is a potent antagonist against $\vec{z}$ $\mathrm{mu}$ receptors it is much less potent against delta and kappa receptors, which could also play a part in the central control of respiration.

Because the effects of naloxone are small the $\stackrel{\mathbb{Q}}{-}$ clinical application of these findings is probably $\vec{\oplus}$ limited. Although naloxone lacks appreciable side $\stackrel{\infty}{N}$ effects, even in large doses, it is obviously less potent than other analeptics, although occasional patients may show large responses. Our studies do show that endorphins have a modulatory role in the respiratory response to carbon dioxide in both normal subjects $\frac{\circ}{\Phi}$ and patients with chronic airflow obstruction, and also have an inhibitory effect on tidal breathing in these patients. Changes in medullary endorphin concentrations may therefore influence the control of breathing.

We thank Dr Neil Pride for helpful discussion and Sterling-Winthrop Ltd for supplying naloxone.

\section{References}

${ }^{1}$ Weil JV, McCullough RE, Kline JS, Sodal IE. Diminished ventilatory response to hypoxia and hypercapnia after morphine in normal man. $N$ Engl $J$ Med 1975;292:1103-6.

${ }^{2}$ Akil H, Mayer DJ, Leibeskind JC. Antagonism of stimulation-produced analgesia by naloxone, a narcotic antagonist. Science 1976;191:961-2.

${ }^{3}$ Simantov R, Kuhar MJ, Uhl GR, Snyder SH. Opioid peptides and enkephalin: immunohistochemical $\Theta$ mapping in rat central nervous system. Proc Natl Acad Sci USA 1977;74:2167-71.

${ }^{4}$ Alder MW. Opioid peptides. Life Sci 1980;26:497-510.

5 Atweh SF, Kuhar MJ. Autoradiographic Localisation of opiate receptors in rat brain. II-The brain stem. Brain Res 1977;129:1-12.

${ }^{6}$ Florez J, Mediavilla A. Respiration and cardiovascular 
effect of met-enkephalin applied to the ventral surface of the brain stem. Brain Res 1977;138:585-90.

${ }^{7}$ Moss IR, Friedman E. B-Endorphin: effects on respiratory regulation. Life Sci 1978;23:1271-6.

${ }^{8}$ Lawson EE, Waldrop TG, Eldridge FL. Naloxone enhances respiratory output in cats. J Appl Physiol 1979;47:1105-11.

9 Chernick V, Madansky D, Lawson EE. Naloxone decreases the duration of primary apnea with neonatal asphyxia. Pediatr Res 1980;14:357-9.

${ }^{10}$ Moss IR, Scarpelli EM. B-Endorphin central depression of respiration and circulation. J Appl Physiol 1981;50:1011-6.

"Willer JC, Boureau F, Dauthier C, Bonora M. Study of naloxone in normal awake man: effects on heart rate and respiration. Neuropharmacology 1979;18:469-72.

12 Fleetham JA, Clarke H, Dhingra S, Chernick V, Anthonisen NR. Endogenous opiates and chemical control of breathing in humans. Am Rev Respir Dis 1980;121:1045-9.

${ }^{13}$ Santiago TV, Remolina C, Scoles V, Edelman NH. Endorphins and the control of breathing. N Engl J Med 1981;304:1190-5.

14 Zimmerman PV, Connellan SJ, Middleton HC, Tabona MV, Goldman M, Pride NB. Postural changes in rib cage and abdominal volume motion coefficients and their effect on the calibration of a respiratory inductance plethysmograph. Am Rev Respir Dis 1981;123:211 (abstract).

is Milic-Emili J, Grunstein MM. Drive and timing components of ventilation. Chest 1976;70:131-3.

${ }^{16}$ Read DJC. A clinical method for assessing ventilatory response to carbon dioxide. Austr Ann Med 1967;16:20-32.

${ }^{17}$ Milic-Emili J, Whitelaw WA, Derenne JP. Occlusion pressure-a simple measure of the respiratory centre's output. N Engl J Med 1975;293:1029-30.

${ }^{18}$ Lederer DM, Altose MD, Kelsen SG, Cherniack NS.
Comparison of occlusion pressure and ventilatory responses. Thorax 1977;32:212-20.

${ }^{19}$ Rebuck AS, Campbell EJM. A clinical method of assessing the ventilatory response to hypoxia. Am Rev Respir Dis 1974;109:345-50.

${ }^{20}$ Ngai SH, Berkowitz BA, Yang JC, Hempstead J, Spector $S$. Pharmacokinetics of naloxone in rats and in man: basis for its potency and short duration of action. Anaesthesiology 1976;44:398-401.

${ }^{21}$ Rebuck AS, Woodley WE. Ventilatory effects of hypoxia and their dependence on $\mathrm{PCO}_{2}$. J Appl Physiol 1975;38:16-9.

${ }^{22}$ Cameron IR. The investigation of the respiratory response to hypercapnia. Bull Eur Physiopathol Respir 1979;15:213-20.

${ }^{23}$ Berger AJ, Mitchell RA, Severinghaus JW. Regulation of respiration. N Engl J Med 1977;297:92-7.

${ }^{24}$ Lundberg JM, Hokfelt T, Fahrenkrug J, Nilson G, Terenius L. Peptides in the cat carotid body (glömus caroticum): VIP-enkephalin-and substance P-like immunoreactivity. Acta Physiol Scand 1979;107:27981.

${ }^{25}$ Wharton J, Polak JM, Pearse AGE et al. Enkephalin-, VIP- and substance P-like immunoreactivity in the carotid body. Nature 1980;284:269-71.

${ }^{26}$ Pokorski M, Lahiri S. Effect of naloxone on the relationships between carotid chemoreceptor and ventilatory responses to hypoxia and hypercapnia. Clin Respir Physiol 1980;16:216-7P (abstract).

${ }^{27}$ Martin WR, Eades CG, Thompson JA, Hoppler RE, Gilbert PE. The effects of morphine- and nalorphinelike drugs in the non-dependent and morphinedependent chronic spinal dog. J Pharmacol Exp Ther 1976; 197:517-32.

${ }^{28}$ Lord JAH, Waterfield AA, Hughes J, Kosterlitz HW. Endogenous opioid peptides: multiple agonists and receptors. Nature 1977;267:495-9. 